\title{
Index of first lines and authors
}

\author{
Index of first lines (English verse) \\ Verses believed to be unique to Burley (among contemporary manuscripts) \\ are marked with an asterisk
}

\section{First line}

${ }^{*}$ A bird did fly from Essex cage

A certayne old cooke cald his dog cuckold

A Lady once that lately was besped

A learned Bishop of this land A mayden faire I dare not wed A page, a knight, a vicount \& an Earle

A puritane is such a wayward thing

${ }^{*}$ A tankard can do as much as a Kan

A Taylor thought a man of upright dealing

Item

341

572

550

600

A vertuous Lady sitting in a muse 599

After those reverent papers whose soule is

Although the vulgar yelde an open eare,

An unmaried man in the nominative case

And of the whole worlde as thou wast thempresse.

And since the glorious fether of thy wing
And thou thi self herein shalt allso live

And where the Christall Thamis wont to slide.

Are woemen fayre? yea passing fayre to see so

${ }^{\star}$ Are woemen foule? so foule you can abyde them

Arithmatique nine digits and no more.

At lenght by the wondrous worke of fate

Behold this litle volume here enrold

Beside we may have lyinge by our sides

Both robd of ayre wee both ly in one ground

${ }^{*}$ Brabus of late hath often boldly sed

Brave impe of Bedford, growe apace in bountie

By childrens birth \& death I am become

Cambden the nourice of antiquitie

Clara half angry with my baudy song 
Cocklowell would have the divel his guest

Come Madam come all rest my powers defy

${ }^{\star}$ Commend her? no. I dare not terme her fayre

${ }^{*}$ Couldst thou young Neptune number all the sand

Did hee dy young? ô no, that cannot bee

Downe came grave ancient sergiant Crooke

Enjoy this bondage, make this prison knowe

Faustus stabd flora and would you know why

Fayre Valentine since once your welcome hand

From Katherines docke was lanch'd a Pinke

From such a face whose excellence

${ }^{*}$ Gaze on frayle man, my dust commands thee stand

God works wonders now and than

Hast thou beene lost a month, and can I bee

He dide, and after him his brother dide

He fed his cubs with fat of all the soyle

He nowe is gonne; the whiles the foxe is crept

Here lies a fayre wife in earth foule \& dirty

Here lies one dead under this marble stone

${ }^{\star}$ Here lies one had a great deale of witt

${ }^{\star}$ Here lies one had a great deale of worth

Here lyeth a man like hive without honny
${ }^{\star}$ I that the higher half of Loves

*I will no more on progresse I

If in his study Hamon take such care

Here uninterred suspends (though not to save

Hobson lies here intombd amongst his betters

How happy is hee borne or taught 357

${ }^{\star}$ Hym for a rare preacher men do account

I am unable (yonder beggar creys) 367

I had my mony and a frend, I did them both preserve

I lov'd thee once; Ile love $\wedge^{\wedge} \mathrm{no}^{\wedge}$ more

I once lov'd peace but cannot now abide itt

If Puresby it should come to passe

Ile tell you how the rose did first

Immortal man of glory! whose brave hand

Immortall spirite of Philisides 516

In that o Queene of Queene[s] thy birth was free

Is not christchurch a goodly Vine 598

It is inoughe to do our smale devotion

It is not longe, since these two eies behelde

Lament you shcollers all

${ }^{\star}$ Lett me dy my deare unlesse I love thee

Light fingered Catch to keep his hand in ure

Like Esops fellow slave o Mercury 377

${ }^{\star}$ Loe now hee shineth yonder $\quad 359$

Marriage (sayth one) hath oft

${ }^{\star}$ Most gracefull Mary [Lady] mother of that pearle

$541 / 612$ grow red 
${ }^{*}$ Motion begets heat, and thus wee see it proved

Much meat doth gluttony procure 603

Musitian and Logician

My love doth fly with wings of feare

${ }^{*}$ My sonn receave these lines, and happy bee

${ }^{\star}$ Nature was here so lavish of her store

Nature waxing old began this for to desire

Ne any poet seeks him to revive 509

Ne Troynovant, though elder sister shee

New freinds are no freinds; how can that be true?

${ }^{\star} \mathrm{O}$ eyes what do you see

O noble spirite lyve there ever blessed

$O$ vaine worldes glory and unstedfast state

${ }^{\star} \mathrm{O}$ what a blisse

${ }^{\star}$ Oh that there weare a Muse that never writt

${ }^{\star}$ On the seaven \& twentieth $\wedge$ day $\wedge$ of June

${ }^{\star}$ One holy even when winters nights wax longe

One onely lives, her makers ornament

Or scorne or pitty on me take

*Our paradice is in a payre of dice

Out of a fyred ship which by no waye

Philo with 12 yeares study hath beene greevd

Phisitians say Tobacco's good: 'tis true

Pilott or pirat thou hast lost thy Pinke

Provide therefore (ye princes) whilst ye live
Rawlings so deeply hath vowed nere more to come

Scilla is toothles yet when shee was yong

Seest thou those jewells which she weares

Sextus on a spleene did rashly sweare

*Silvius lies here within this grave 597 Since all things love why should not wee?

Since thou art dead Clifton, the world may see

Sith that we are free borne

So pytifull a thinge is suters state 506

*Some in hast

St: Jhons is governed only by a P 560 Still to be neate still to be drest 398

Such happines have they, that do imbrace

Tell me who can when a player dies

The ape was stryfull and ambicious

The charge is wonderous great

The Dolphines twisting each on others syde

*The K. of Isles is dead

Thee to invite the great God sent his stare

There was at Court a Lady of late 563 Therefore in this half happy I do reade

This Iron worlde

This is all a womans worke

*This Lyfe it is not life, it is a sight 360

*Those drossy heads and irrepurged braynes

Thou callst meffeminate for I love womens joyes

Thou in the feilds walks out thy supping howres

Thy father all from thee by his last will 
Thy flattering picture Latrine is like thee

Thy Sins \& heyres may no man equall call

*Twixt Lords and servants some great difference make

Two by themselves each other love \& feare

Tyme delayed new hope of healpe still breedes

Uncivill death which wouldst not once conferr

Under an undermind \& shott bruisd wall

Underneath this sable herse

Was ever contract better driven by fate

Well: I may now receave \& dy, my sinn

${ }^{*}$ Went you to conquer? and have so much lost

What heat of learning kindled your desire

What is our life? a play of passion 551 What soddayne chance hath dark't of late 535

When Bruno first embrac'd his [wife] in bed

*When Fortune Love and Tyme bad me be happie
When you awake dull Brittaynes and behold

Whether that soule which now comes up to you

Who so hath leave within this booke to prye

*Why are maydes witts then boyes of lower strayne?

*Why call wee old men grave? why, tis cause then

Why cruel death should honest Owen catch $481 / 588$

Within this marble caskett lies 584

Within this marble cave here lies 423

*Wolsey thy tombs imperfect, so's thy colledge

Wrong not deare empresse of my hart

Yet it is comfort in great languishment

*Yf for his witt Ulisses bee renowned

Yf idle travellers aske who lies here

You Ladies that do London love so well

You meaner beauties of the night 543

Your mistris that you follow whores still taxeth you

368

\section{Index of authors (English verse)}

About two-fifths of the poems are anonymous; for the rest, authorship has been proposed with various degrees of certainty, the most conjectural of such attributions being marked with asterisks in the index.

\begin{tabular}{lr|lr} 
Author & Item & $\begin{array}{l}\text { Browne, William } \\
\text { Cholmley, Henry }\end{array}$ & 558 \\
Andrewes, Francis & 550 & Clanricarde, Richard Burke, 4th & $607^{\star}$ \\
Ayton, Sir Robert & 356,596 & Earl of & 382 \\
Bartlet, John & $390^{*}$ & Constable, Henry & 394 \\
Bastard, Thomas & 561 & Corbett, Richard & $481 / 588^{\star} 598^{\star}$ \\
Beaumont, Francis & 537 & Cranfield, Lionel & $539 / 611^{\star} 18^{*}$
\end{tabular}




\begin{tabular}{lr|lr} 
Donne, John & $361,362-377,384$, & Milton, John & $608^{*}$ \\
& $391,392,548$ & Morley, George & $423 / 584$ \\
Drummond, William & 538 & Parrott, Henry & 378 \\
Harington, Sir John & $528,559,581$, & Porter, Walter, & $529^{*}$ \\
& 599,609 & Pyne, John & 580 \\
Harington, John, of Stepney & 595 & Raleigh, Sir Walter & 551 \\
Herrick, Robert & 574 & Randolph, Thomas & $555,614,615$ \\
Holland, Hugh & 359 & Rowley, William & 583 \\
James I, King & $534,535,582$ & Spenser, Edmund & $497-524$ \\
Jonson, Ben & $336,339,398,399$, & Strode, William 564, 566, 568, 589,591 \\
& 533 & Townley, Zouch & 604,605 \\
Juxon, William & 592 & Williams, John & $541 / 612^{*}$ \\
Lewis, William & $530,544^{*}$ & Wotton, Sir Henry & $357,543,553^{*}$, \\
Mathew, Sir Tobie & 393 & &
\end{tabular}

\section{Index of first lines (non-English verse)}

\begin{tabular}{|c|c|c|}
\hline $\begin{array}{l}\text { First line } \\
\text { Latin }\end{array}$ & Item & $\begin{array}{l}\text { sensit } \\
\text { Lumine Acon dextro caruit }\end{array}$ \\
\hline Accii sinceri Sannazzari & 407 & Leonella sinistro \\
\hline Adeste Orbilii quot estis omnes & 429 & Machina quae bis sex tam juste \\
\hline $\begin{array}{l}\text { Aethera sol peragra, tu Joiiose } \\
\text { inclyte terras }\end{array}$ & 416 & $\begin{array}{l}\text { dividis horas } \\
\text { Mens bona non vaga sors virtus }\end{array}$ \\
\hline $\begin{array}{l}\text { Area parva Ducum totus quem } \\
\text { respicit Orbis }\end{array}$ & 358 & $\begin{array}{l}\text { non gratia Regis } \\
\text { Musicus et Logicus Downhalt iace }\end{array}$ \\
\hline arbariem Hermoleus Latio qui & & ecce Johannes \\
\hline dep & 432 & Natum $n$ \\
\hline $\begin{array}{l}\text { Borbonius, bonus orbi: } \\
\text { Consuluit nuper Phoebus Cecilus }\end{array}$ & 472 & $\begin{array}{l}\text { r tibi parva vo[?], et } \\
\text { e parvus }\end{array}$ \\
\hline Heros & 610 & Pauperiem vatum nemo mirabit, \\
\hline $\begin{aligned} \text { eform } \\
\text { tete }\end{aligned}$ & 420 & \\
\hline itior reprobat, debellat [] & 402 & Christus \\
\hline $\begin{array}{l}\text { Dum Venus et Veneri positis Mari } \\
\text { gratior armis }\end{array}$ & 408 & $\begin{array}{l}\text { Petri hostis Petrus Christi insidiat } \\
\quad \text { oculi }\end{array}$ \\
\hline $\begin{array}{l}\text { Esse tuam patrem Papam } \\
\text { Burghesius inquit }\end{array}$ & 480 & $\begin{array}{l}\text { Phi nota[m?] fetoris, Lippus malus } \\
\text { omnibus Lotis(?) }\end{array}$ \\
\hline $\begin{array}{l}\text { In Cratere meo Thetis est } \\
\text { commixto Lyeo }\end{array}$ & 403 & $\begin{array}{l}\text { Politiorum amator ille verborum } \\
\text { Quilibet si sit contentus }\end{array}$ \\
\hline $\begin{array}{l}\mathrm{I}[\mathrm{n}] \text { felix ingens Anima atque } \\
\text { miuse beatas }\end{array}$ & 467 & $\begin{array}{l}\text { Quod per armes vitam } \\
\text { Religio mihi non Regis Pax public }\end{array}$ \\
\hline $\begin{array}{l}\text { Jesuitae cur te si quaeris post } \\
\text { fulmania(?) primi }\end{array}$ & 414 & $\begin{array}{l}\text { non Rei } \\
\text { Res est in silvis nigro depicta }\end{array}$ \\
\hline Lipsius ut moritum exacto frigore & & colone \\
\hline
\end{tabular}


Sanguis effusi imposita est hac poena Davidi

Sava quatergermino Belgarum gloria lustro

Scilicet authori Satane si credere fas est,

Si Lapis est unus dic qua fuit arte Levatus

Si mihi quem cupio cure Mildreda remitti

$\mathrm{Su}[\mathrm{pe}] \mathrm{r}$ quae eram, nec eram quae [enim?], nunc dicor utcumque 422

Te nisi solus amo peream Clorinda, vel illud

Te virum durum vocat ac honestum

Trina mihi ducta est variis aetatibus armis

Ursa quid infrendis? [.]

Uxorem ducit qui macham in vertice cornu

Uxorem fraudas tua fraudet amica maritus

\section{Italian}

Alla Zuecca intendo che vuol fare 413

Ardea, di Lidio il vago 354

Beneficii il Pastori dona non vendi

Latrai a i ladri a gli amanti tacqui

Negra si, ma sei bella, o di Natura

Non fatto Papa Tosco perche ogli e patro

Queste poche d'honor frondi novelle

Qui giace Il Cardinale Colonna Romano nato

Sciolta il crin, rotta i panni, e nuda il piede

Sovra a liquidi Campi

\section{French}

C'y gist le pere, cy gist la mere $\quad 468$

C'y gist sans drap linceul ny nape 482

Si quelque Diable est veritable $\quad 478$

\section{Index of authors (non-English verse)}

\section{Author}

Latin

Amalteo, Girolamo

Casa, Giovanni della (Formosa)

Castellani, Giacomo

Killigrew, Katherine

Menini, Ottavio

Nequam (Neckam), Alexander

Passerat, Jean

\section{Item Italian}

425

408

354

496

416

433

471 410
Achillini, Claudio

294

Grazzini, Anton Francesco (Il Lasca)

Marini, Giambattista $\quad 355,409$ 


\section{Incipit index (English letters)}

Note: Salutations, such as 'Sir', are omitted. Some items begin with a foreign phrase or sentence, but are indexed here because they are substantially in English. The English translations of the letters of Quintus Aurelius Symmachus are included. Official and diplomatic communications are excluded.

\section{Incipit}

Ad bonitatem requiritum integritas boni; 459

After many great losses, and many yeares sorrowes,

After your long sylence I no lesse desired then I expected

Albeit I doubt not (by gods leave) to have a mutuall intersight Albeyt in my letter of the last of February

Albeytt commendation of children to theire parents

All this while like a silk worme I worke myself into a bottome

Although I know your modesty is a neere ally to vertue,

Amias my most faithfull and carefull servante,

As neither nature nor custome hath mad me a man of complement, 281

As well in Love as in greife why should not sylence

But that I have much ernest sorrow for the losse

Early did I hope this morning to have had myne eyes blessed

Excuse the infinite faultes in the writing

Good God! now there is nothing belonging to men certayne

I am come but a litle nerer to you, and I am already

I am filled with joy for the recovery of your health,

I am in [no] way guilty of sylence, 19
I am intangled in a double affliction by being accused

I am no great Voyager in other mens works

I am so far from telling you what day I may meete you

I have receaved a very kind letter from you

I have receaved a very kind letter from you (2nd version)

I have the honor of a letter from your Lordship

I imagine in you, bycause I find in my self,

I know you remember that the same greife with yours

I love and admire your vertue: $\quad 27$

I must wonder that since my comming to London

I pray you bestow my commendations

I presume you rather try what you can do in me,

I promised a jorney like godfathers which promise \& vow

I remember when Scaramella a Segretarie to the Venetian

I send to you now that I may know how I do

I undertake a labourious buisines to offer to persuade

I use that confidence with you which your self hath given

I very much rejoyce that you are chosen Consul

I will answere your letter bycause I remember 
I will have leave to speake like a lovor,

If I had remembred that I should have wanted your sight

If you please to write I will with all gladnes answere your letters

In this sickly dotage of the world where vertue languisheth

In your whole fortune you have not adventured so much;

It is an old saying, honor increaseth Arts,

It is for the publique good this new charge is committed to you

It is ill conceived that fortune wanteth judgment:

It is my fortune that wheresoever I sett my foote

It is worth my wondring that you can complayne

It may seem strang to you that upon so short a commendation

Least intermission of writing should seem a vice

Me thinks your good discretion should not call ill fortunes faults

Men were meant to bee impatient of delayes

Mille volte ringratio $\mathrm{V}$ [ostra] E[ccellenza]

Most feared \& beloved most sweet \& gratious soveraigne

Most mightie kinge, my not lesse deare $\wedge$ dread $\wedge$

Moste gracious Soveraigne if either bitter teares,

My dearest Lord and brother I humbly beseche you

My love finding passage by so fitt a messenger

My Love makes me write unworthy lettres
Omnes omnia bona dicere et laudare fortunas meas

Only in obedience I send you some of my paradoxes;

Out of the love I beare to some of your frends

Suesse is a towne of honest inhabitants

That increase of his greatnes although it were enough

That love which went with you followes \& overtakes

That which I conceived in opinion and hope

That which I conceived in opinion, and hope, (variation)

That your fortunes so abundantly prosper

The badnes of theire minds is manifest

The first act of that play which I sayd I would go

The publique magistrate to you, and a private compassion to mee

The relacion of occurrences here I leave to this gentleman

The succession of frendship is to bee affected

The Tyranny of a suddaine raging sicknes

They say that when cockles thirst for ayre,

They speak not vaynely, who say mens understandings

This bearer a gentleman of Germany is worthy of your acquaintance:

This is the fift letter that hath died in your service

Tis true you abound in all abilities of nature and mind,

To excuse, where there is no respas 
To resume therefore, the conclusion of my last,

\begin{tabular}{|c|c|}
\hline & $\begin{array}{l}\text { You have recompensed a long } \\
\text { sylence }\end{array}$ \\
\hline & $\begin{array}{l}\text { You know what hath passed } \\
\text { betweene you and mee }\end{array}$ \\
\hline & $\begin{array}{l}\text { You may thinke itt somewhat } \\
\text { strang for me, }\end{array}$ \\
\hline 16 & $\begin{array}{l}\text { You require of me longer letters } \\
\text { You say you expected longer letters }\end{array}$ \\
\hline & $\begin{array}{l}\text { from me } \\
\text { You speake like a noble and worthy } \\
\text { frend }\end{array}$ \\
\hline & $\begin{array}{l}\text { You understand the new honor ou } \\
\text { Prince hath conferred }\end{array}$ \\
\hline & $\begin{array}{l}\text { Your letter of the } 26 \text { of May came } \\
\text { unto my hand }\end{array}$ \\
\hline
\end{tabular}

To write to you newes were to give you a coppie of the original

Whilst I lived in sylence and was wholy removed from desires

Yf the memory of our old frendship remayne constant

You excuse your sylence I confesse with an elegant exposition,

You excuse your sylence I confesse with an elegant exposition: my hand

\section{Index of authors (English letters)}

As with the poems, authorship has been proposed with various degrees of certainty, the most conjectural of such attributions being marked with asterisks in the index.

\begin{tabular}{|c|c|c|c|}
\hline Author & Item & $\begin{array}{l}\text { Fletcher, Nathaniel } \\
\text { Goodere, Sir Henry }\end{array}$ & $\begin{array}{r}457^{*} \\
462\end{array}$ \\
\hline Babington, Anthony & 243 & Raleigh, Sir Walter & 291 \\
\hline Donne, John & $284^{\star}, 285^{\star}, 299$ & Rich, Penelope, Lady & 282 \\
\hline $435-43$ & $8,440-451,455^{\star}$ & Sidney, Sir Henry & 252,254 \\
\hline & $6,458,459,461^{*}$ & Sidney, Sir Philip & \\
\hline 464 & $65,466,485,547$ & Symmachus, Q. Aurelius & $2-40,298$ \\
\hline Elizabeth I, Queen & 244 & Tresham, Francis & \\
\hline $\begin{array}{l}\text { Essex, Robert Devere } \\
\text { 2nd Earl }\end{array}$ & aux, & Wotton, Henry & $7,439,463$ \\
\hline
\end{tabular}

\section{Incipit index (other English prose)}

Incipit

A Courtier to the French King: that his eares receaved

A fayre \& ready one of your hand musick for

A gentleman of Naples begging a pension

142

A gratious kind of pardoning not to take notice
Item

A King should use his prerogative as rarely

A letter hath beene spread here agaynst the Citty of Verona's 69

A memoryall of sure Resolvement at his Majestie

A partie in Senat presently after the death of the French King: 136

A preacher begging almes told the audience

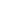


A Preist near St. Hieronimo in Venice

A prisoner in Venice rejoiced when he heard

A soldier should draw the platforme of battayles

A soule in a fatt body lies soft and is lost [loth?] to rise

A Venetian Ambassador when he saw Phillip the $2 \mathrm{~d}$

About a picture of my Lord of Essex which Brassadonna

Acts that fill Princes coffers are often the ruine

After my hartie comendacions his Majestie hath

After my harty commendacions unto your good Lordships 248

After my very heartie Commendacions, His Majesty

After our $\wedge^{\wedge}$ very $\wedge$ harty commendacions, wee received

$\mathrm{Al}$ the matter in discourse heere, is a maske represented by the Q: 62

All states are ungratefull: \& so theire ministers

All woemen are for one use though in divers tytles

An Advertisement was brought from Rome by a preist

An objection being made against the acting

Anteus when he touched the earth recovered his strenght

Any Friar may quit his monasterie that pretendeth

At Luca every houre is rung an Ave Maria bell

Atheist in affliction like blind beggars:

Because I know not whither I shall live to come before the Lords

Before men leap into great businesses they must see
Beinge arrived at Angiers on Fridaie nyght last 266

Being not able yet to make any final judgment

Boterg a Jesuit of the Cittie of Bene of whome it is said

By the Turks law all contracts written in Latin may be broken

Causabong to Rhony presenting his Athaneus:

Cavaliere Guar:[di?]: The Court of Rome is like the sea

Charles V. That the Diets of Germany were like

Cheri yelded to the Duke of Savoy with condition

Christmas Lords only know theire ends

Christning a ceremony of the church:

Concerning the enterteyment given to our Irish Earles

Cosimo de Medici gave his son this precept:

Court motions are upp and downe; ours circular:

Denials from Princes must be supplemented with gratious usage

Deodati of Padre Paulo: huomo cubiculare on what syde soever

Discourse with $\wedge$ all $\wedge$ men as nere as you can

Don Francesco Count di Castro lay from Saturday

Don Pedro in 88 being asked why he did not runne

Errors like rivers the further they run the more they increase

Experience is deerely bought, when itt never learns to do

Extreames are equally removd from the meane 
Every great vice is a pike in a pond

Every man a letter beyond himself is a foole

Fatali inavertenze. The League of Cambray against the Venetians

Few dare write the trew news of theire chambers

First it was and is concluded, established, and agreed,

First that God may blisse your travell you must principally apoint

Flattery is increased from a pillow 313

Fowlenes is loathsome: can thast bee so too

Fulgentio burned at Rome in July 1610 for denying the pope

God hath made one worke of substance

Great must be the art of that man, that keeps himself afloate

Having expounded here unto your Highnes Resident

Having formerly given you a generall accompt

Having made foure voyages to Rome \& concluded the peace 417

Havinge had this daie \& yesterdaie our [reinforcement?]

Hee came of a Parent, that counselled the state

Hee that first considers what should bee the latter,

Hee that sleepes in the cradle of security

Heere hath beene this week a solemne professing

Henry 3. A famine so violent that the king was enforced

Henry 3. A parliament at Oxford chose $24{ }^{\wedge}$ comites $^{\wedge}$ call a parliament, 201

Henry 3. was complaynd off for his private electing cheife Justice 196 Honoria Denny

Humbly shew, That wee cast our selves att his Majesties feet

I A.B. do truly, and syncerely acknowledge, professe,

I am adjudged to dy for a plott plotted but not acted;

I am enjoyned ii things by the Lords, The first to saye

I am not of that seard impudency that I dare defend weomen

I am sure there is none of the forbidden fruite left

I cannot att this tyme sett my penn to paper, without resolving

I Determined since the veiw that I tooke here of $\mathrm{Mr} \mathrm{H}$.W

I have besydes this place of my charge in divers other,

I have Cause first to thanke god with my heart,

I have not been so pitifully tyred with any vanyty

I have nothinge to saye to the preamble of my Lord of Canterbury

I heare myself diversly censured for the discovery

I say againe the body makes the mynd:

If Ariana ymperit be not onlie for knowledge

Illustrissimo Nani Venetian Ambassador when the Pope

Immoderate liberality is a weake meanes to win love,

Immoderate liberality is a weake meanes to win (longer version)

In difficult tymes States send into the eares of the people 
In Naples the general of the Camp permitteth 149

In $\wedge$ the $\wedge$ banishment of the Jesuits from Venice

In things we know wee should not do as those that fall

It is the wholesomest getting a stomake

It may please your Lordshipps, I shall humbly crave

It was unlikely that the Venetians would apprehend

It was written from Bologna that the Image

Jesuits are like apricocks, heretofore,

Jurea called Stallabium, for a collony of horse the Romans kept 185 Justices of the Peace have the felling of the underwoods;

Leagues and contracts of Princes last no longer

Least intermission of writing should seeme a vice

Leo V. offered in the Venetian troubles 3000 loaves

Macguire the Vaut courier of Tyrones company

Many statesmen hunt theire owne fortunes

Many thinke there are as many miseries beyond happines,

Marino Grimani Duke of Venice (weakned with a double tertian 51

Masters of houses like false pillars which seeme to hold upp

Maximilian I. was wont to say that he was King of Kings

Men must beware of running downe steepe hills

Molin to Sir H.W. of the death of the French King

Mounsieur Moulin in Orleans

My Lord Montjoy reprehended

100 $\mathrm{y}$ the King for taking tobacco 171 My Lord of Essex after being made counsellor

My Lord Treasurer to Sir H.W. concerning his following the King

My Lordes and you Gentlemen of this lower Chamber

My wordes your highnesses having been long and greatly

Next to noe wife and children, your owne wife

No mans bounty is much loved that is not merely future

Now at lenght after almost 5 months deliberation,

Nullos esse Deos inane cælum 494

Often sleeping are so many trialls to dy

On Tewsday the xth of February, the [?] of the Citty of Derrye 246

One document I have learn'd in Lucca not to medle

Our carts are never worse employed then when

Our moste bounden duties and fortunes moste humblye

Out of Arithmetike sprong musicke

Pasquin. He died Spanish and lived French

Pere Cotton receaving the Kings hart

Presently uppon the King of France his death a miracle

Princes minds \& favors more transitory then others

Princes must choose instruments par negotiis

Ride si sapis ô puella, ride if thou beest wise laugh:

Rolfe Winwood in a horse tayle 
Shall shee bee guide to all creatures which is her self one

Signor Hercule de Salice: that when the league

Since the example of Alexander 6, and then Bianca Capella 169

Sir Edwin Sands: No difference conceaved from and betweene 270

Sir F. Bacon in parlament I sh after a very fayre speech

Sir Henry Wooten his Majesties Embassador at Venice

Sir Robert Cecil accused to his Majestie by Udal

Sir Tho: Parry departed hence yesterday having received from the K: 52

Sixtus 4th built the bordello in Rome

Sleepe is deaths picture drawne to the life,

So farre as the Lordes here assyned 3 houres after

Some 3 weeks before the arrival of his Majesties book

Sometymes flashes are flung abroad $\wedge^{\circ}$ of purpose ${ }^{\wedge}$

Soveriano the Inventor of and cause of the building of Palma

Squire my advice to thy master shalbee as a token

Such is ower extreame want of raynes in these parts

That chambering is esteemed a civiller quality then playing

That mony is nothing but a thing that art

That smale service which your Lordship left in my hand

The 16. of May the Bishop of Feltre

The 28 of April 1605 the K: made his entry into Paris

The best bedfellow for all tymes in the yeare
The Bishop of Filadelphia in Venice being asked 152

The Bishop of Winchester denied delivery of the great seale

The Camarieri of Contarini at his retorne

The censure lately sett forth a Rome against certayne books

The Count Olivares Spanish Ambassador to Sixtus V

The Duke in Florence seldome came where his brethren were

The Duke of Ferrara preceded in Italie accept

The Duke of Nevers to Villeroy that if he ceased

The English Jesuits for the special favor

The extortion that is in the mighty, the oppression

The fertility of Piemont may be imagined by the neerenes

The French King after he is dead for certayne dayes

The French King by his Ambassador

The Jesuits after vespers say always divers ave maria's

The Jesuits in theire bande That unlesse the Colledg

The judgments which are here made of forraine actions

The K: maketh great instance to restablish the Jesuits

The King he governeth all

The King of Swethlands son being feasted with a dance

The Lord of Arundel that commandeth the regiment

The Lord Threasurer Burleigh speaking of a kings authority

The maine matter which is here intended to is the treaty of $318 \quad$ Flanders 
The marriages are these: The

Prince of Mantua

The mayntayning of Paradoxes breedes a custome

The murtherer must be wrought to the fact:

The news which we have here latly out of Spaine

The night heats in Venice for your grosse bodies

The Nuns of St. Lorenzo (gentlemens daugthers)

The officers of the Turk in theire prayers

The Pope by executing Fulgenzio sheweth to the world

The Pope Paulus V. when Fulgentio preached at Venice

The Prince Donato very often used to Ambassadors

The Prince of Jenville [Joinville] who a little whyle since

The Prince of Parma; of Orange; Sixtus Vs;

The Prince of Venice in this like the sun doth effect

The Princesse of Orang hath lately obteyned leave of the K:

The Queene proceeded against the Erle of Essex

The Queen's farwell to my Lord of Essex

The Queen was wont to cal Sir R. C[ecil]

The religion of Malta is to destroy the Turks and infidels

The sense: to let the "Quene" understand of matters

The Signoria of Venice farmeth $2 / 3$ of theire datii:

The Spanish Ambassador in Venice 99 The Spanish Ambassador needed no spectacles in Venice 173 had her meat

The State of the Treaty in Holland 233

The states generall of the Unyted

Provinces

The subject which doth here amuse us most in Paris

The Theater of the affayres of Christendome

The Turk hath a close grate with a curtayne in a rome

The treaty of peace in the Low countries

The wisedome of action is discretion

Thebe a Queene of Lombardy had Corduba for her dowry:

There are not two such acres in all the country

There fell out an accident here a few dayes since

These reasons may be gathered dissuadinge thexecution

This last week we had executed heere a certayne Italian

Those of the religion have latly made an end of theire Synod

To affect yea to effect theire owne deathes

To demande heere the liberty of burial for his Majesties subjects

Too great benefitts from Princes to subjects are dangerous:

Trustie and right welbeloved Counsellors

Trusty and welbeloved such and so many are youre dispatches 226

Trusty and well beloved We greet you well

Truth is every mans by assertinge

Tyme was never but a minute old 331 Tyrants shed blood for pleasure, kings for necessity 
Upon the breaking of the Treaty of Peace, the Archdukes 232

Uppon arrival of the news of the French King's death

Want and abondance equally informe a rectified mind 326

Wee the Commons assembled in Parliament doe clayme

When it shall please God to bring thee to mans estate,

When Sr. F. Bacon was told

A Bishop was

Wheareas it is the pleasure of Sir John Popham knight,
Whereas yt is the pleasure of Sir John Popham knight,

Who reades this paradoxe but thinks me more fantastique

Witt and a woman are two frayle things

Woemen are not so tender fruite, but that they beare

Your best three piled mischeife comes from beyond sea

Your Lordship hath reason to say that the imposterous straw miracle

\section{Incipit index (non-English prose)}

\section{Incipit \\ Latin}

Abirrant iam novem dies ex quo

Roma: ad veneram,

Cum Serenissimus Archidux

Mathias frater noster

carissimus

Cum verum presentiium deplorata statio perdita casi

224

Deformior vivit

Fratississime Princeps ac Duc. Ad Ser [.] 396

Generosissimo Domino Virtute, ingenio, et stemmatu antique

293

Henricus Wottoniius, Anglo-

Cantianus, Thomae Optimi viri 44

Hic iacet Robertus Devreuxes Vir bonus et ama[n]dus 395

Justos et nos segneris per multa damna christiano orbi

Mirabene fortassio (vir insignissime) qua confidentia

Negate intercessionem sanctori

Nego Doctores ipsi aut Universitatarum seu Gymnasiorum

Nimia Lectio effecit stultitiam

Nuntius Papalis questus est uperiori (septimana?) in Collegio

Pacem servare inter Principes Christianes

Quam apposite Reipublicam Venetiae Tiberius Imperator

Quam miser est qui vocandi argumentum non habet

Qui vostrum proximus inviserit Westphalos

Quod M. Cato olim dixit Mirabile si aruspix aruspicem videns

Salutem eisque boni incrementio tibi ex animo

Sanctam Catholicam et Apostolicam Romanam ecclesiam

Significatium mihi est quid in $\mathrm{ma}\left[{ }^{* *}\right]$ ta urbe vostra

Sunt in hoc Collegio, quae prius erat Anglorum hospitale,

Superacti me pronititudine, Illustris ac Generosissime Domine, 292

Superioribus mensibus ad nostram et Apostolica sedis

Tu ni me ita es pro uno 
Italian

Aggiungeret a Serena Majesta la sadisfattione grande Arrive in questa citta il Signor Cavaliere Arrigo Wottoni

Christiani son gente senza legge: Hebrei legge e ne gente:

Gia che i segni della misericordia del signor Dio

Ha tel opinione N. Sig. Della bonta di V.A.

Il signor Giacobo Lyndsay [qualunque?] normale mi ha fatto sapere

La poca pratica che lo nel scrivere bono in questa vulgare

Le lettere della Maiesta Vostra presentatea dal Signor

Monsignore Illustrissimo Io son venuto a V.S. Illustrissimo

Per essere hora mai a veria informata la Serenissima Vostra
Se ben Io son comparso qua spose voleo

Se L'Italia volese, come prio ben considerarium diligentemente 261

Visto per Maesei delle Requeste Ordinarie del Re Guidici

\section{Spanish}

Es de prossoponem que el dictio Francesco: Ravaillart

He recibido la carta di V[ostr]a S[erenissim] a Ill[ustrissi]ma

Si Dios ne habiera dado a las al cuerpo conform

\section{French}

Articles, accordes entre les Ambasadeures des Royes, Princes,

Mons. Mon Cousin votre lettre de Vienne du vj Septembre devant nous 